\title{
A DIALÉTICA DAS DUAS CIDADES NA TEOLOGIA/FILOSOFIA DA HISTÓRIA DE SANTO AGOSTINHO
}

Marcos Roberto Nunes Costa*

SíNTESE - Em sua obra A Cidade de Deus, Santo Agostinho procura definir e relacionar dialeticamente os conceitos de Cidade de Deus e Cidade terrena, considerando a origem, natureza, desenvolvimento e fins das duas cidades. É aí que encontramos a sua teclogia-filosofia da história, que nos faz identificar as duas cidades com certas realidades históricas: Cidade de Deus como sendo a Igreja, Cidade terrena como sendo o Império Romano. Contudo, Agostinho adverte que estes termos não são sinônimos.

PALAVRAS-CHAVE - Santo Agostinho, Cidade de Deus, Cidade terrena, Filosofia da História.
ABSTRACT - In its work The City of God, St. Augustine tries to defines dialeticamente the concepts of City of God and Terrestrial City, considering the origin, nature, deveiopment and ends of the two cities. It is there that we found a theology-philosophy of the history, what makes us to identify the two cities with certain historical realities: City of God as being the Church, Terrestrial City as being the Roman Empire. However, Augustine informs that these terms are not synonyms.

KEY WORDS - St. Augustine, City of God, terrestrial City, Philosophy of the History.

\section{Introdução}

Quem ler a obra A Cidade de Deus de Santo Agostinho, seu principal escrito de cunho político-social, perceberá que existe uma certa confusão ou ambigüidade quanto à definição e relação entre os termos Cidade de Deus e Cidade terrena.

Se a nível conceitual existe esta dificuldade, do ponto de vista prático, ou seja, quando Agostinho aplica esses conceitos à realidade histónica, ou quando procura fazer uma leitura da humanidade à luz de seus conceitos teónico-doutrinais (teologia/filosofia da história), os problemas aumentam, tomando sua doutrina éticopolítica muitas vezes confusa e contrađitória. Com efeito, acontece ser um certo conceito, ou termo, usado em determinado momento para designar uma realidade concreta e, em outros momentos, esse mesmo termo ser usado, também, para designar outra realidade, às vezes até contraditória. Por vezes, dois termos diferentes aparecem, em alguns momentos, como análogos e, em outros, como distintos.

* Professor da Universidade Católica de Pernambuco - UNICAP, Recife e Doutorando em Filosofia pela PUCRS.

v. 43

$n^{9} 4$ 
Diante de tais problemas, dedicaremos esta pequena comunicação à análise dos conceitos de Cidade de Deus e Cidade terrena; Cidade de Deus e Igreja; Igreja e Império (Estado); Cidade terrena e Império Romano, no que se refere à origem, natureza, desenvolvimento e fins, e como se relacionam dialeticamente na obra $A$ Cidade de Deus de Santo Agostinho.

\section{1 - Origem e Natureza das Duas Cidades}

Apesar de se referir por diversas vezes às duas cidades durante os dez livros que compõem a primeira parte da obra $A$ Cidade de Deus, é na segunda parte (Livros XI a XIV) que Agostinho define a origem e a natureza das "duas cidades". A essa parte recorreremos em grande escala neste tópico.

No que concerne às duas cidades - Cidade de Deus ou Celestial e Cidade Ímpia ou terrena - os problemas começam, quando procuramos encontrar suas origens, ou identificar os seus fundadores.

Agostinho começa a segunda parte de A Cidade de Deus (Livro XI, capítulo 1) falando da existência de "duas cidades": Cidade de Deus e Cidade dos ímpios: "[...] damo-nos conta da existência da Cidade de Deus, de que, pelo amor que nos inspirou o seu Fundador, aspiramos a ser cidadãos [...] e a dos ímpios e soberbos, que, privados da luz imutável e comum [...]" (De Civ. Dei XI, 1). Nesse primeiro momento, relaciona-se a origem da Cidade de Deus com o momento da criação dos santos anjos por parte de Deus, bem como se atribui à queda ou desobediência dos anjos como origem da Cidade ímpia: "alguns anjos pecaram e foram recaídos nos abismos deste mundo, cárceres para eles, até à condenação final e futura no dia do juízo" (De Civ. Dei I, 33). Daí que, "no princípio [...] Deus estabeleceu uma divisão entre a Cidade de Deus, que não peregrina nesta mortalidade, mas é eternamente imortal, quer dizer, entre os santos anjos, que se encontram unidos com Deus e não desertaram nem desertarão, e os que, ao abandonarem a luz eterna, se tornaram trevas" (Idem XI, 28). ${ }^{1}$

Portanto, num primeiro momento, o nascimento das duas cidades aparece como anterior à criação do homem tendo como origem, uma, a criação dos santos anjos por parte de Deus - a Cidade de Deus - outra, a rebeldia dos anjos - a Cidade impia. Trata-se, portanto, de duas cidades de natureza mística ou metaempírica, isto é, uma referência aos conceitos metafísicos de bem e mal.

Entretanto, já no Livro XII, que trata da criação do primeiro homem e de sua queda, depois de afirmar, com convicção, ser o homem um ser criado no tempo: "devo dizer, sem vacilar, não haver o homem existido antes do tempo e haver 0 primeiro homem sido criado no tempo" (De Civ. Dei XII, 15), e mais do que isso, que Deus o fez nas mesmas condições dos anjos, isto é, com livre arbitrio, Agostinho passa a relacionar a homem as origens das duas cidades. Ou seja, pelo livre

1 Essa idéia reaparece nos últimos livros da segunda parte da obra quando o Autor diz: "[...] de maneira alguma e em tempo algum, os espírtos que chamamos anjos começaram por ser trevas. No mesmo instante que Deus os criou foram luz; criados, não para serem ou viverem simplesmente, mas ainda iluminados para viverem vida feliz e sábia. Alguns anjos, afastando-se da luz, não lograram a perfeição da vida sábia e feliz, que não é tal senão eterna [...]" (De Civ. Dei XIX, 11). 
arbítrio uns permaneceram em Deus, criando a cidade dos bons, outros, desobedeceram a Deus, criando a cidade dos maus. Ou melhor, quando os homens se juntaram aos anjos, com eles formaram as sociedades dos bons e dos maus, pois, na realidade, não há uma separação entre as cidades dos.anjos e as dos homens, pelo contrário, trata-se das mesmas cidades místicas do bem e do mal. Pois, como o próprio Agostinho nos diz, "não há inconveniência ou incompatibilidade entre a sociedade dos homens e a dos anjos e, assim, que não existem realmente quatro cidades ou sociedades, duas humanas e duas angélicas, mas apenas duas cidades ou sociedades de bons e maus, homens ou anjos" (Idem XII, 1). Em ambos os casos, "enquanto uns se mantiveram no bem, comum a todos, que é para eles o próprio Deus, e em sua eternidade, verdade e caridade, os outros, embriagados por seu próprio poder, como se fossem seu próprio bem, declinaram do bem beatífico, superior e comum a todos, aos seus particulares" (Idem XII, 1).

Como se vê, não se trata de duas novas cidades, mas das mesmas cidades fundadas pelos anjos, ou seja, o bem e o mal presentes nos atos da vontade humana.

Nessa perspectiva, Cidade de Deus e Cidade Celestial são sinônimos; ambas não passam de uma mesma natureza mística ou meta-empírica; ou seja, o conceito metafísico de bem, cujo fundador é o próprio Bem supremo - Deus, que perpassa os atos da vontade humana. O termo Cidade de Deus é usado para designar a Cidade Celestial, enquanto bem peregrino na terra à espera do verdadeiro bem, Deus, eterno ou celestial.

A Cidade dos ímpios, por sua vez, é o mesmo que Cidade terrena. Ambas não passam de uma mesma natureza mística ou meta-empirica, enquanto conceito metafísico do mal que perpassa os atos da vontade humana.

Mesmo quando Agostinho fala das duas cidades como cidades dos homens concretos, como por exemplo: "Daí que, sendo tantos e tão grande os povos disseminados por toda terra, [...] não formem senão dois gêneros de sociedade humana, que, conforme as nossas Escrituras, podemos chamar de duas cidades. Uma delas é a dos homens que querem viver segundo a carne, a outra, a dos que querem viver segundo o espírito..." (Idem XIV, 1), isso não passa de uma aplicação alegórica do termo para designar a presença de duas realidades metafísicas: o bem e o mal, permeando as ações humanas "quando, portanto - escreve Agostinho - o homem vive segundo a verdade, não vive segundo ele mesmo, mas segundo Deus, pois Deus é quem disse: Eu sou a verdade. Quando vive segundo ele mesmo, quer dizer, segundo o homem, não segundo Deus, indubitavelmente vive na mentira" (Idem XIV, 4 ) ${ }^{2}$ Daí ter dito o Santo Filósofo: "dos que vivem segundo a carne e outros segundo o espírito originaram-se as duas cidades diversas e contrárias entre si [...] ou uns vivem segundo o homem e outros segundo Deus" (Idem XIV, 4).. E conclui: "uma é a sociedade dos homens piedosos e a outra dos homens ímpios, eada qual com os anjos de seu grêmio, nos quais precedeu, ali o amor a Deus e aqui o amor a si mesmo" (Idem XIV, 13).

2. Afinal, "o homem não se tornou semelhante ao diabo por ter carne, de que o diabo carece, mas por viver segundo si mesmo, quer dizer segundo o homem" (De Civ. Dei XIV, 3). 
Como se vê, não há uma separação entre o plano espiritual e o material, entre as cidades dos anjos e as cidades dos homens. Para Munõz Vega, esse seria um sinal claro do monismo agostiniano, ao atribuir uma unidade entre os planos do espiritual e do material, ao incluir na origem dos conceitos das "duas cidades místicas", duas realidades contrárias: os anjos (realidade ou substância espiritual) e os homens (realidade empírica): "O mérito eminente de sua concepção teológico-social está precisamente em haver posto em evidência a unidade do plano eterno da criação, [...] pelo qual os homens e os anjos estão destinados a formar um só corpo social e mistico". ${ }^{3} \mathrm{E}$, segundo o mesmo comentador, isso só foi possível graças à interiorização da vontade e da ação, através da qual se dá a transposição do mundo social ao mundo interior, a qual, por sua vez, foi um dos caracteres inovadores da "filosofia cristã" agostiniana: "Sua originalidade consiste precisamente nesta transposição que permite decifrar o mundo social e histórico através do próprio mundo interior". ${ }^{4}$ Pela interiorização da vontade e da ação, Agostinho transforma a realidade social em um conceito mistico, o qual se encontra antes no mundo da consciência do que no da realidade empírica.

Outra observação importante nos traz Manfredo Ramos ao nos lembrar que antes de tudo "Agostinho não é maniqueu, ou dualista, mas monista. É Deus, Uno e Criador, o princípio e fim de tudo". ${ }^{5}$ Logo, a origem da Cidade do mal não poderia estar em Deus, mas tão somente no homem; ou, melhor dizendo, na livre escolha do homem, que escolhendo mau criou a Cidade ímpia. Assim sendo, as duas cidades do bem e do mal - repetimos - são conceitos místicos, os quais se encontram antes na consciência dos homens do que na realidade empírica.

Agostinho conclui a série de argumentos que desenvolveu durante os quatro primeiros livros da segunda parte de A Cidade de Deus (Livros XI a XIV), acerca da origem das duas cidades, com a célebre afirmação: "Dois amores fundaram, pois, duas cidades, a saber: o amor próprio, levado ao desprezo a Deus, a terrena; o amor a Deus, levado ao desprezo de si mesmo, a celestial. Gloria-se a primeira em si mesma e a segunda em Deus, porque aquela busca a glória dos homens e tem esta por máxima glória a Deus, testemunha de sua consciência..." (Idem XIV, 29).

\section{2 - Desenvolvimento histórico das duas cidades}

Se, quanto à origem e natureza das duas cidades, já existe uma certa tendência em identificá-las com a realidade concreta dos homens reais, quanto ao desenvolvimento, o risco é ainda maior. Nomeadamente quando, a esse respeito, Agostinho passa a classificar as sociedades humanas como esta ou aquela cidade mística.

3 MUNÒz VEGA, Pablo C. Introduccion a la Sintesis de San Agustin. Quito: Ediciones de la Universidad Católica, 1981, 314 p. p. 161. (El mérito de su concepción teológico-social está precisamente en haber puesto en evidencia la unidad del plan eterno de la creación [...] por el que los hombres y los ángeles están destinados a formar un solo cuerpo social e místico). frar el mundo social e histórico através del proprio mundo interior).

5 RAMOS, Francisco Manfredo T. A Idéia de Estado na Doutrina Ético-Politica de Santo Agostinho: um estudo do epistolário comparado com o De Civitate Dei. São Paulo: Loyola, 1984, 370 p. (Coleção "Fé e Realidade" n. 14) p. 298. 
Antes de fazermos a divisão e classificação dos periodos ou estágios da história da humanidade, apresentados como momentos sucessivos do desenvolvimento das duas cidades, gostariamos de reiterar que se trata, mais uma vez, de uma leitura alegórica da realidade. As duas cidades - Cidade de Deus e Cidade terrena - continuam sendo de natureza mística ou meta-empírica como outros tantos conceitos metafísicos de bem e de mal constantes nas ações humanas. $O$ que Agostinho faz nos quatro livros (XV a XVIII) de A Cidade de Deus é uma leitura do desenvolvimento da história da humanidade à luz de dois conceitos: o do bem , que significa a presença de Deus na história, e o do mal, que significa a desobediência a Deus, por parte dos homens. Enfim, o que temos é uma teologia/filosofia da história.

Agostinho começa o livro XV com a seguinte colocação: "Dividi a humanidade em dois grandes grupos: um, o dos que vivem segundo o homem; o outro, 0 daqueles que vivem segundo Deus. Misticamente, damos aos dois grupos o nome de cidades, que é o mesmo que dizer sociedades de homens" (XV, 1).

Segundo G. Sabine, o fato de Agostinho dividir a história da humanidade em dois grandes grupos, atribuindo um sentido religioso a esta distinção, está diretamente relacionado à sua visão dualista de homem (corpo e alma), marcada pela divisão dos interesses humanos: de um lado, os interesses terrenos centrados no corpo; de outro, os interesses ultramundanos que pertencem à alma. Para ele, "Santo Agostinho fez desta distinção a chave para compreender a história da humanidade, que está e estará sempre dominada por uma luta entre duas sociedades: de um lado se encontra a cidade terrena, a sociedade fundada nos impulsos terrenos, apetitivos e possessivos da natureza humana inferior; por outro, a Cidade de Deus, sociedade fundada na esperança da paz celestial e a salvação espiritual". ${ }^{6}$ É por isso que, conforme vimos anteriormente, Agostinho chega a chamar as "duas cidades" de cidade da carne e cidade do espírito, fazendo uma íntima relação entre os interesses do homem individual e da sociedade em geral.

Agostinho divide a história da humanidade em "seis periodos, correspondentes aos dias da criação, com suas manhãs e tardes, sendo a segunda sempre uma catástrofe, como o dilúvio, a confusão das línguas, a queda de Saul, o desterro, a reprovação do povo hebreu", que significam o movimento dialético de nascimen-

6 SABINE, George. San Agustin. In: Historia de la Teoria Politica. Madrid: Fundo de Cultura Econômica, 1988, p. 148. (San Agustin hizo de la distinción la chave para compreender la história humana, que está y estará siempre dominada por la lucha entre llas dos sociedades: de un lado se encuentra la ciudad terrera, la sociedad fundada en los impulsos terrenos, apetitivos y posesivos de la naturaleza humana inferior; por otro, la Ciudà de Dios, sociedad fundada en la esperanza de la paz celestial y la salvación espiritual).

7 CAPÁNAGA, V. Apud. FRAILLE. Guilherme. San Agustin. In: Historia de la Filosofia II: el judaismo, el cristianismo, el islam y la filosofia. 2. ec. Madrid: La editorial Catolica, 1956, p. 227. (Coleção Biblioteca de Autores Cristianos - BAC). (en seis periodos, correspondientes a ios dias de la criación, con su manãna y su terde, siendo la segunua siempre una catástofre, como el diluvio, la confusión de lenguas, la caida de Saul, el destierro, la reprobación del pueblo hebreu) Cf. FÉDOU, Michel. Santo Agostinho (354-430): A Cidade de Deus, 413-426. In: CHÄTELET, François; DUHAMEL, O.; PISTER, E. (Orgs). Dicionário de Obras Políticas. Trad. Glória de C. Lins e Manoel F. Paulino. Rio de Janeiro: Civilização Brasileira, 1993, p. 26, que mantém os seis periodos, mas apresenta uma outra divisão: "De Adão ao Dilúvio; do Dilúvio a Abraão; ce Abraão a Davi; de Davi à deportação para a Babilônia; dessa deportação ao nascimento de Cristo; e, por fim, desse acontecimento ao fim dos tempos, que será ele próprio o advento cie um 'sétimo dia'" 
tos e mortes sucessivas das "duas cidades", ou o desenvolvimento progressivo de ambas no tempo. ${ }^{8}$ Esta sucessão de etapas ocorrerá até o juízo final, quando acontecerá a separação ou sintese final: "o triunfo definitivo do bem sobre o mal, da luz sobre as trevas e do reino de Deus sobre o de satanás, é o sétimo período, já ultraterreno, que corresponderá ao descanso sabático". ${ }^{9}$

\section{1 - Éstágios das Duas Cidades na História da Humanidade}

As duas primeiras cidades nasceram, ou estão representadas, nos dois primeiros filhos de Adão, Caim e Abel, que teriam sido criados na seguinte ordem: "O primeiro filho dos dois primeiros pais do gênero humano foi Caim, pertencente à cidade dos homens, e o segundo Abel, participante da Cidade de Deus" (Idem $\mathrm{XV}, 1)$.

Como Caim matou Abel, Adão gerou um terceiro filho chamado Set, que seria interpretado como obra da graça de Deus. Caim e Set seriam os troncos dos quais se desenvolveriam as duas primeiras cidades. Caim significa a continuidade do pecado, da morte. Set, por sua vez, significa ressurreição, havendo, na interpretação de Agostinho, uma correlação entre Set e Cristo: "A morte e ressurreição de Cristo estão figuradas naqueles dois homens, em Abel, que significa luto, em Set, seu irmão, igual à ressurreição" (Idem XV, 18).

Os descendentes de Caim e Set multiplicaram-se por seis gerações quando 0 sétimo filho de cada um deles deu continuidade às duas primeiras cidades, do mal e do bem. "Caim gerou Enoc e em seu nome fundou uma cidade, a terrena, não peregrina neste mundo, mas apoltronada em sua paz e felicidade temporais [...] Enoc significa dedicação, pois a cidade terrena está dedicada a este mundo, onde foi fundada e tem o fim que apetece e pretende" (Idem XV, 17). Por outro lado, Set gerou Enós, "que significa Homem [...] filho da ressurreição, que vive em esperança" (Idem XV, 17-18), fundou a cidade do bem ou cidade de Deus, peregrina neste mundo à espera da vida eterna.

Os descendentes de Enoc, expandiram o mal, de tal forma que Deus usou de sua ira $e$ mandou o dilúvio para destruir a cidade do mal. Em contrapartida, Deus encarregou Noé, descendente de Enós, de perpetuar a cidade do bem.

Noé, descendente de Enós e de Set, representa a Cidade de Deus peregrina neste mundo. A arca representa a ressurreição da qual sairão novas gerações: "Ao dilúvio, em que foi destruida toda raça da cidade terrena, depois restaurada pelos filhos de Noé" (Idem XV, 20), havendo uma correlaçăo entre a arca e Cristo: "[...] a arca, é sem dúvida, figura da Cidade de Deus peregrina neste mundo [...] que se saiva pejo lenho de que pendeu o Mediador entre Deus e os homens, o homem Jesus Cristo" (Idem XV, 26).

8 O desenvolvimento dessas duas cidades compreende todo o lapso de tempo, também chamado de século, rápida sucessão de nascimentos e mortes, que formam o curso das duas cidades" (De Civ. Dei XV, 1).

9 FRAIlLE, Guilherme, Op. cit. p. 228. (el triunfo definitivo del bien sobre el mal, de la luz sobre las tinieblas y del reino de Dios sobre el de satanás, en el séptimo periodo, ya ultraterreno, que corresponde al descanso sabático). 
Assim, o primeiro estágio das duas primeiras cidades, seria dos dois filhos de Adão: Set e Caim, representando, respectivamente, o nascimento das cidades do bem e do mal, até Noé. Em Noé, teríamos uma pausa que significa o fim do primeiro estágio das duas cidades.

Os filhos de Noé, Sem e Cam, fundaram, respectivamente, duas novas cidades do bem e do mal. Sem, que foi abençoado por seu pai, e Cam, que fora amaldiçoado em seu filho Canaã. Com isso terá início o segundo estágio das segundas cidades.

Como descendentes de Sem e Cam (e Canaã), surgiram dois novos personagens, fundadores de duas novas cidades: Héber, descendente de Sem, que fundou a comunidade do povo Hebreu: "De Héber chamaram-se hebereus e depois, perdida uma letra, hebreus" (Idem XVI, 3), e o gigante Nemrod, descendente de Cam, que fundou a Babilônia: "Cuch, pai do gigante Nemrod, é dos filhos de Cam o primeiro a ser citado [...] Daí o provérbio: Gigante caçador contra o Senhor, como Nemrod. O princípio de seu reino foi Babel..." (Idem XVI, 3), ou seja, "Babilônia, que quer dizer Confusão" (Idem XVI, 4), representando, respectivamente, o início do terceiro estágio das duas cidades, do bem e do mal.

Por causa das maldades da cidade do mal, a Babilônia, Deus destruiu novamente a cidade terrena e, na sua misericórdia, mandou mais um sinal: Abraão, descendente de Héber e Sem. Em Abraão teríamos uma pausa, seria o fim do terceiro estágio das duas cidades.

Abraāo, por promessa de Deus, teve um filho de nome Isaac, o qual teve dois filhos: Jacó e Esaú, que seriam o início do quarto estágio das duas cidades. De Jacó nasceu o povo chamado Israel, e de Esaú nasceram os judeus: "os dois filhos de Isaac, a saber, Esaú e Jacó, figuram dois povos, o dos judeus e o dos cristãos" (Idem XVI, 42).

Dos descendentes de Isaac, ou Abraão, até a época dos reis, sucedeu uma série de personagens, até que veio Saul, primeiro rei que, por sua maldade, fora vencido e morto. Com ele, toda a descendência da cidade terrena. Assim, esse rei representa o fim do quarto estágio das duas cidades.

Por misericórdia divina, veio Davi para suceder Saul. Desse sucessor descenderam quatorze gerações, até chegar Cristo. Assim, de Davi a Cristo teríamos o quinto estágio das duas cidades.

$E$, finalmente, de Cristo ao juizo final, se dará o sexto estágio do embate das duas cidades quando, depois da vitória do bem sobre o mal, no juizo final, a humanidade alcançará a paz eterna, ou verdadeira felicidade. Será o descanso final, o sétimo estágio, correspondente ao descanso sabático na criação do mundo.

As sucessivas mortes e nascimentos das duas cidades representam a queda (morte), ou o pecado do homem, e a sua ressurreição (nascimento), símbolo ou prenúncio da ressurreição final, quando haverá a separação ou vitória do bem sobre o mal. Enquanto isso não chega, as duas cidades caminham juntas: "com efeito, ambas as Cidades enlaçam-se è confundem-se no século até que o juízo final as separe" (Idem I, 35). 


\section{3-Fins das Duas Cidades}

No que se refere aos fins das "duas cidades", já no prólogo ao primeiro livro de $A$ Cidade de Deus, Agostinho anunciava qual seria o fim da Cidade de Deus: "A gloriosa Cidade de Deus prossegue em seu peregrinar através da impiedade e dos tempos, vivendo, cá embaixo, pela fé, e com paciência espera a firmeza da mansão eterna, enquanto a Justiça não se converte em juiz, o que há de conseguir por completo, depois, na vitória final e perfeita paz" (Idem I, Prólogo). Isso acontecerá na soberana cidade onde "a vitória é a verdade, a honra é a santidade, a paz é a felicidade e a vida é a eternidade" (Idem II, 29).

Diferentemente da Cidade de Deus, peregrina neste mundo, que tem sua continuidade e plena reaiização na Cidade Celestial, "a cidade terrena, não peregrina neste mundo, mas apoltronada em sua paz e felicidade temporal [...] está dedicada a este mundo, onde foi fundada e tem o fim que apetece e pretende [...] essa cidade tem princípio e fim terreno" (Idem XV, 17).

Enquanto os cidadãos da Cidade terrena se contentam com a felicidade temporal, os da Cidade de Deus esperam com paciência a "verdadeira felicidade" a ser alcançada na vida eterna. Por isso nos diz Agostinho: "No tocante a ambas as cidades, a do diabo e a de Cristo, e seus dois reis, o demônio e Cristo [...] naquela, os seus príncipes, comem de madrugada, ou seja, antes da hora devida, porque não esperam a felicidade real no século futuro, a verdadeira, desejando ser felizes o quanto antes com a felicidade do mundo. Ao contrário, os príncipes da cidade de Cristo esperam com paciência o tempo da felicidade autêntica" (Idem XVII, 20).

Como se vê, Agostinho estabelece uma íntima relação entre a natureza éticomoral das sociedades e os fins a que tenderão, dando uma dimensão teleológica à sua doutrina ético-moral, quando, no que concerne aos fins dos principios do bem e do mal, responderá "ser a vida eterna o soberano bem, a morte eterna o soberano mal" (Idem XIX, 4). E, como conseqüência, anuncia que devemos bem viver, para obtermos aquela e evitar esta, pois "o uso das coisas temporais relaciona-se, na terra, com a obtenção da paz terrena e, na Cidade de Deus, com a obtenção da paz celeste" (Idem XIX, 14).

É por isso que Agostinho encerra o Livro XIX, fazendo uma estreita relação entre vida moral, que levamos aqui na terra, e os fins últimos das duas cidades: "Na paz final, entretanto, que deve ser a meta da justiça que tratamos de adquirir aqui na terra, como a natureza estará dotada de imortalidade, de incorrupção, carecerá de vícios e não sentiremos nenhuma resistência interior ou exterior, não será necessário a razão mandar nas paixões, pois não existirão [...] Tal estado será eterno e estaremos certos de sua eternidade. Por isso, na paz dessa felicidade e na felicidade dessa paz, consistirá o soberano bem" (Idem XIX, 27). Eis o fim último da Cidade de Deus.

Ao contrário, "para os que não pertencem à referida Cidade de Deus haverá miséria eterna, por outro nome segunda morte, porque nem a alma, nem o corpo vivem. A alma porque estará separada da vida, que é Deus, e o corpo, porque sofrerá dores eternas" (Idem XIX, 28). Eis o fim último da Cidade terrena ou Cidade dos ímpios. 


\section{4-É A Cidade de Deus a Igreja?}

Outros dois termos que possuem uma relação confusa em A Cidade de Deus são os conceitos de Cidade de Deus e Igreja. Cabe, portanțo, tentarmos delimitar as suas semelhanças e diferenças, para uma melhor compreensão dos mesmos.

Os problemas em torno da relação entre os conceitos de Cidade de Deus e Igreja começam, quando, por diversas vezes, em A Cidade de Deus, Agostinho usa estes termos como análogos, ${ }^{10} \mathrm{o}$ levariam alguns comentadores de Agostinho a afirmarem que a Cidade de Deus é o mesmo que a Igreja.

C. Journet, por exemplo, escreve: "A Igreja é a Cidade de Deus - Sob seu duplo aspecto, primeiro peregrino, depois glorioso, a Igreja e a Cidade de Deus coincidem. Trata-se de duas visões, dois conceitos, dois aspectos de uma realidade idêntica. Tal é o pensamento de Agostinho". ${ }^{11}$

De certa forma concordamos com as afirmações de C. Journet, desde que entendamos o conceito de Igreja num sentido meta-empírico, como a congregação dos homens que vivem sob as verdades universais do cristianismo. Neste caso, seria preferivel usarmos o termo "religião cristã". O próprio Agostinho chega a fazer uso deste termo como sinônimo de Cidade de Deus: "Ana, que significa Graça, falou com espírito profético à religião cristã, a Cidade de Deus, cujo rei e fundador é Cristo [...]" (De Civ. Dei XVII, 4). Assim sendo, ambos os termos (Cidade de Deus e Igreja) têm o mesmo sentido, ou seja, são de natureza mistica; representam a presença de Deus, ou do bem, na história. Nesse sentido, o termo igreja não se refere à realidade empírica, hierárquica e sacramental - a Igreja Católica.

Por outro lado, $\mathrm{H}$. Marrou, discordando das palavras de C. Journet, afirma que "ela é sem dúvida a Igreja dos predestinados e dos santos, cujo acabamento escatológico Agostinho contempla pela fé e em esperança. Mas esse conceito não se encerra na pura Igreja escatológica, ela se realiza empiricamente na história pelo instrumento querido de Deus, da Igreja, hierárquica e sacramental", ${ }^{12}$ fundada por Cristo. Já W. Walker é mais categórico ao dizer: "[...] a Igreja visível e hierarquicamente organizada é a Cidade de Deus". ${ }^{13}$

Outros, contrariamente às duas interpretações anteriores, não vêem nenhuma relação entre A Cidade de Deus e a Igreja Católica. A Cidade de Deus seria uma realidade puramente meta-empírica que não possui nenhum sinal empírico. Essa é a opinião de Newton Bignotto, por exempio, ao afirmar que: "Contrariamente a H. Marrou, que acreditava que a Cidade de Deus e a Igreja se confundiam, pensamos

10 Vejamos algumas dessas passagens: "Com efeito, a casa do Senhor, A Cidade de Deus, a saber, a Igreja, eaifica-se em toda terra depois do cativeiro, em que, escravos dos demônios, gemiam os homens libertados pela fé e transformados hoje em pedras vivas do divino edificio" (De Civ. Dei VIII, 24); "Mas há filósofos, contra cujas calúnias defenderemos a Cidade de Deus, quer dizer, a Igreja [...]" (Idem XIII, 16); "Mas sempre manifestando fielmente, como é certo, que tais acontecimentos não se deram e foram registrados sem alguma prefiguração do futuro e que devem referise a Cristo e à sua Igreja, que é a Cidade de Deus" (Idem XVI, 2).

11 JOURNET, C. Apud. RAMOS, Francisco Manfredo T. op. cit. p. 256.

12 MARROU, H.-I. Apud. RAMOS. Francisco Manfredo T. op. cit. p. 257.

13 WALKER, Williston. Agostinho. In: História da Igreja Cristā. 2. ed. Trad. Glênio Verga dos Santos e Durval da Silva. rev. Cyril E. Richardson; Wilhelm Panck e Robert T. Handy. Rio de Janeiro: Juerp/Aste, 1980, v. 1, p. 239. 
que a Cidade de Deus é uma comunidade fora do tempo, dedicada ao amor, que nada tem a ver com as instituições humanas. Não possuindo um signo visível $[\ldots] " .14$

Na nossa opinião, a interpretação de H. Marrou parece mais defensável, pois além de manter a dimensão mística da Igreja, enquanto realidade meta-empírica, faz da Igreja empírica, hierárquica e sacramental (Igreja Católica), uma espécie de protótipo da Igreja mística ou Cidade de Deus.

Os argumentos para concordarmos com H.-I. Marrou, encontramo-los no próprio Agostinho quando da sua luta contra as posições radicais dos bispos donatistas. Esses bispos, por um lado, relacionavam a Igreja com a própria Cidade de Deus e, por outro, identificavam a Cidade de Deus com a Igreja Católica, advogando e radicalizando a idéia de uma Igreja empírica pura, só dos santos e predestinados.

É evidente que, num primeiro momento, como vimos, Agostinho usa os termos Cidade de Deus e Igreja como análogos, enquanto a cidade mística do bem. Entretanto, num segundo momento, identificará, também, a Igreja Católica com a Cidade de Deus; só que, diferentemente dos bispos donatistas, será uma Igreja de santos e pecadores. Assim, do mesmo modo que a Cidade de Deus caminha peregrina, aqui na terra, misturada com a cidade dos impios até chegar à separação final, quando haverá a vitória do bem sobre o mal, na Igreja empírica, hierárquica e sacramental também convivem, juntos, santos e pecadores, bons e maus: "A Igreja é, pois, agora o reino de Cristo e o reino dos céus. $E$ agora com ele reinam também seus santos, é certo que de forma diferente de como reinarão mais tarde, mas a cizânia não reina com ele, embora cresça com o trigo na Igreja" (Idem XX, 9).

Mais do que admitir a presença de bons e maus dentro da Igreja, Agostinho, num primeiro momento, admite a presença de cristãos entre os ímpios, tendo para com estes uma atitude de benevolência. Assim, no livro primeiro de A Cidade de Deus, em capitulo intitulado: "Filhos da Igreja que há encobertos entre os ímpios e falsos cristãos existentes na Igreja", diz: "Lembre-se, todavia, de que seus próprios inimigos em suas fileiras têm latentes vários de nossos futuros concidadãos, para não juigar estéril, quanto a eles, a paciência que os suporta como inimigos, à espera da ventura de recebê-los como confessores. Lembre-se, também, de que, enquanto neste mundo peregrina, vários que lhe estão unidos pela comunhão dos sacramentos não estarão associados à sua glória na eterna felicidade dos santos [...] Com efeito, ambas as Cidades enlaçam-se e confundem-se no século até que o juizo final as separe" (I, 35).

Estas foram as primeiras posições de Agostinho frente à questão donatista, que corresponde ao tempo em que este exortava os cristãos a testemunharem acolhida e benevolência aos pagãos vítimas do saque a Roma: "Dai provas de doçura, compartilhai os sofrimentos alheios, cuidai de seus doentes [...] Eis o que o Cristo espera de vós. Deixai os pagãos maldizerem sua desgraça" (Serm. 81, 9).

14 BIGNOTTO, Newton. O Conflito das Liberdades: Santo Agostinho. Sintese Nova fase. Belo Horizonte, 19 (58): 237-359, 1992, p. 354. Cf. SABINE, George. San Agustin. In: Historia de la Teoria Politica. Madrid: Fundo de Cultura Econômica, 1988, p. 148, que è da mesma opinião ao afirmar: "A Igreja como organização humana visivel não era para ele o mesmo que o reino de Deus" (La iglesia como organización humana visible no era para él lo mismo que el reino de Dios ). 
Entretanto, tempos depois, quando a querela donatista parecia resolvida, e muitos de seus defensores já haviam retornado ao seio da Igreja, diante do crescimento do pelagianismo e das ações terroristas de pequenos grupos de bandoleiros radicais, dentre eles os circumcilliones, que pretendiam desestruturar a paz social e a Igreja, Agostinho, aos poucos, mudaria de opinião e passaria a defender posições que entrariam em contradição com seus ideais antidonatistas.

Primeiro defenderia a idéia de que a Igreja Católica seria a legítima representante de Cristo na terra e, conseqüentemente, a única via de salvação para o homem. Exemplo disto é a carta ao conde Bonifácio, que diz: "Fora da Igreja católica, que é o único corpo de Cristo, a ninguém vivifica o Espírito Santo [...] pois, não é participante da divina caridade quem é inimigo da unidade. Nâo têm, por conseguinte, o Espírito Santo os que estão fora da Igreja [...] Quem não participa da 'paz católica' pela comunhão, na mesma Igreja, dos sacramentos cristãos, sobretudo do mesmo pão eucarístico, não pode chegar um dia à comunhão da vida eterna" (Ep. 185).

À medida que o pelagianismo crescia, Agostinho radicalizava suas novas posições, passando a defender a exclusão do seio da Igreja daqueles que não confessassem ou comungassem da mesma fé: "Os homens, renascendo pela graça, como que tirados de um acervo de ruínas [...] são inseridos no corpo de Cristo [...] no templo vivo de Deus, que é a sua Igreja [...] Fora deste edifício, [...] a vida humana não é, senão, infelicidade e deveria antes chamar-se morte que vida" (Ep. 187).

Mais do que defender a exclusão dos inimigos da Igreja, Agostinho passaria a defender, também, a correção dos inimigos, chegando, inclusive, a pregar o uso da força, ou o poder coercitivo contra estes: "Os que na Igreja de Cristo têm opiniões perigosas e más, se, corrigidos, resistem com contumácia, se negam a emendar-se das pestiferas e mortiferas doutrinas e persistem em defendê-las, tornam-se hereges e, uma vez fora da Igreja, olhamo-los como inimigos [...] Mas sempre, para amar os inimigos, os fiéis lhe exercitam a benevolência ou a beneficência, quer com eles procedam por conferências pacificas, quer por terriveis castigos" (De Civ. Dei XVIII, 51).

Ao justificar o uso da força contra os inimigos da Igreja, Agostinho seria levado, também, a admitir ou justificar a intromissão do Estado (Império Romano ) nos assuntos da Igreja, bem como o inverso, o que levaria a mais uma confusão conceitual: Se a Igreja e o Estado seriam ou não a mesma coisa.

\section{5 - É a Igreja o Império (Estado)?}

A querela com os donatistas teria fim, pelo menos oficialmente, com a Conferência de Cartago em 411. Entretanto um pequeno grupo de radicais - os circumcilliones - continuavam atiçando as classes exploradas contra a Igreja Católica e o Império. Daí que uma questão que começara com um problema religioso se transformava num problema social e político; fato que levou o Estado a intervir $e$ a usar a força para combatê-los.

No início, Agostinho insistiu em que o Estado não devia intervir em assuntos religiosos e que à fé se devia chegar pela conviç̧ão e não pela força. Para este, a intervenção do Estado nas questões religiosas só iria piorar as coisas, pois "nin- 
guém pode ser constrangido, sob a ameaça da vioiência, a abraçar a fé” (Ep. 185). Para Agostinho, a coerção religiosa era incompativel com a liberdade de escolha, pois, conforme vimos, a liberdade de escolha é essencialmente uma faculdade interior que não pode ser coagida senão pela verdade divina.

Entretanto, diante das atrocidades cometidas pelos circumcilliones e das pressões de seus colegas bispos, finalmente Agostinho aceitou a intervenção do Estado na questão donatista.

A carta ao conde Bonifácio deixa clara a mudança de opinião de Agostinho quanto à intervenção do Estado nas questōes religiosas, sem contudo perder seu espirito conciliador: "Sem dúvida alguma, vale mais levar os homens ao amor de Deus pela instrução que constrangê-los pelo temor e pela dor do castigo [...] Mas, a experiência nos provou, e ainda prova cada dia, que o emprego do temor e da dor foi profícuo a muitos que se tornaram depois mais bem dispostos a se instruírem e a porem em prática o que haviam aprendido - e conclui - existem uns que a bondade torna melhores, mais numerosos são aqueles que só podem ser corrigidos pelo temor" (Ep. 185).

Entretanto, ao admitir o uso da força, Agostinho adverte os "oficiais imperiais" de que não se esqueçam da virtude da mansidão da Igreja, da qual são filhos; na repressão aos crimes cometidos pelos inimigos cismáticos, que se use o castigo, mas não lancem mão da pena de morte.

Em carta ao Procônsul Apríngio, irmão do tribuno Marcelino, Agostinho diz: "teme, pois, conosco o juizo de Deus pai [...] Luta contra os maus com bondade [...] Deixa espaço para penitência aos inimigos vivos da Igreja" (Ep. 134). A mesma orientação seria dada pouco depois a Doçura, Procônsul substituto de Apríngio: "Tu não recebestes de nenhuma lei o direito de vida e de morte e os decretos imperiais não prescrevem que um cismático seja condenado à morte" (Ep. 204, 3).

E para demonstrar que não estava pregando a impunidade, mas o uso do "reto castigo", diz: "Não é que queiramos com isto que se dê a indivíduos celerados a liberdade de cometer delitos, mas desejamos que para tal escopo seja bastante que, deixando-os vivos e sem mutilar nenhuma parte do corpo [...] Que sejam arrancados à sua insana agitação e reconduzidos a uma vida sã e tranqüila, ou que, subtraídos às suas obras malvadas, sejam empregados em algum trabalho útil" (Ep. 134).

Por isso, em carta aos oficiais imperiais propõe que se puna ou castigue o malfeitor, não por vingança ou sadismo, maș por amor ou desejo de tornar o infrator feliz, pois "nada é mais infeliz do que a felicidade dos pecadores [...] que devem ser corrigidos com uma aspereza, por assim dizer, benigna" (Ep. 138). E para que isso aconteça, Agostinho recomenda o amor, ou caridade cristã, como princípio regulador na aplicação dos castigos: "Que nada se faça com o desejo de prejudicar, mas tudo pelo amor de ajudar, e não se fará de cruel, nada de desumano [...] Os bons não fazem senão cumprir o preceito de amar com a reta intenção e com a consciência, que Deus conhece, seja quando castigam, seja quando perdoam" (Ep. 153). Os mesmos conselhos seriam dados ao Estado em caso de guerras. Que as mesmas tenham como princípio não a vingança e a maldade, mas o amor ou o desejo de salvação do inimigo em pecado. 
A presença do Estado em questōes religiosas intensificaria cada vez mais o envolvimento recíproco entre Igreja Católica e Estado, que desde o Imperador Constantino, trocavam favores mútuos.

O fato de admitir um envolvimento recíproco entre Igreja e Estado, levou alguns comentadores a afirmarem que Agostinho teria defendido uma posição teocrática. Que a Igreja deveria governar o mundo, através da submissão do Estado à Igreja. W. Walker, por exemplo, diz que "a Igreja visível e hierarquicamente organizada é a Cidade de Deus, a qual deve, cada vez mais, governar o mundo [...] Isso ela faz, na opinião de Agostinho, mediante seu relacionamento íntimo com o Estado cristão, o qual existe não só para preservar a paz mas para agir como um 'pai devoto' junto aos seus cidadãos [...] Entre a Igreja e o Estado ideal deve haver relações mútuas de dependência e obrigações reciprocas"15 Daniel-Rops e G. Sabine, respectivamente, ratificam essas palavras ao afirmarem que "a Igreja tem especialmente o segredo e a guarda da justiça e da caridade segundo Cristo, e como o Estado é legítimo na medida em que se orienta por essas virtudes, resulta daí que a Igreja possui um direito de vigilância sobre o Estado". ${ }^{16}$ Assim sendo, "depois do advento do cristianismo - diz Sabine - nenhum Estado pode ser justo, a menos que seja também cristão". ${ }^{17}$

Quanto a nós, não concordamos com a opinião de W. Walker, Daniel-Rops e G. Sabine, e ratificamos as interpretações de Manfredo Ramos ${ }^{18}$ e Ernest Fortin de que Agostinho não assumiu teoricamente uma posição teocrática. Para Emest Fortin, o fato de Agostinho ter admitido o uso da força para reprimir a heresia donatista, "parece haver sido ditada em grande medida pela natureza política do caso e não por argumentações teológicas". ${ }^{19}$ Pelo contrário, Agostinho deixa bem claro que Igreja e Estado são instituições distintas, embora tenham causas comuns que pedem ajuda mútua. É o que escreve o próprio Agostinho ao Procônsul Apríngio: "[...] uma coisa é o interesse de uma Provincia, outra, o da Igreja: o governo daquela deve ser exercitado com muito rigor, enquanto desta devem-se ressaltar a ciemência e a mansidão" (Ep. 134).

O que o Santo Filósofo propõe é um equilibrio ou justa dosagem entre o "rigor do Estado" e a "mansidão cristã". Esse equilíbrio aparece na carta 153, ao Governador da África, Macedônio: "É útil, portanto, a vossa severidade, por cujo ministério, também a nossa tranquilidade; é útil, igualmente, a nossa intercessão, por cujo ministério também, a vossa severidade é temperada" (Ep. 153).

15 WALKER, Wiliston. op. cit. p. 239.

16 DANIEL-ROPS [Henri Petiot]. O Santo dos Novos Tempos. In: A Igreja dos Tempos Bárbaros. Trad. Emérico da Gama. São Paulo: Quadrante, 1991, p. 54.

17 SABINE, George. op. cit. p. 149. (Después del advenimiento del cristianismo ningún estado puede ser justo, a menos que sea también cristiano).

18 Cf. RAMOS, Francisco Manfredo T. op. cit. p. 336.

19 FORTIN, Emest L. San Agustín. In: STRAUSS, Leo; CROPSEY, Joseph (Comps.). Historia de la Filosofia Politica. Méxido: Fondo de Cultura Economica, 1992, p. 198 (Parece haber sido dictada en gran medida por la naturaleza politica del caso y no por argumentos teológicos). 


\section{6 - A Cidade Terrena e o Império Romano}

Por fim, outros dois termos que, ao nosso ver, se relacionam de forma confusa na obra $A$ Cidade de Deus são os conceitos de Cidade terrena e Império Romano. Aqui nos cabe perguntar: Será o Império Romano a Cidade terrena ou Cidade impia?

Nos primeiros livros, Agostinho tem posições ambivalentes acerca do Império Romano, sendo mais benevolente do que critico para com ele. Assim, num primeiro momento, especialmente o Livro $\mathrm{V}$, justifica o poder temporal de todo $\mathrm{e}$ qualquer reino como sendo de origem divina, havendo, à primeira vista, uma proximidade maior entre Império Romano e Cidade de Deus do que com Cidade terrena. Ou seja, o poder dos reinos terrenos, em si, é um bem (bem menor), ou um dom de Deus. Logo, pertence ao campo da cidade mística do bem. ${ }^{20}$

Assim sendo, o poder terreno do Império Romano é um bem ou um dom de Deus; é fruto da providência divina: "A causa da grandeza do Império romano não é fortuita, nem fatal [...]" (De Civ. Dei V, 1); pelo contrário, "o único Deus verdadeiro que nem em seu juizo, nem em seu auxilio abandona o gênero humano, quando quis e quanto quis, deu o reino aos romanos" (Idem V, 21).

Entretanto, Agostinho reitera que o poder temporal dos reinos terrenos é apenas um "bem menor"; ainda não é a "verdadeira felicidade", que não se encontra senão na vida eterna, em Deus. O poder temporal, Deus o dá aos reinos para que, dispondo de tão sublime bem, possam proporcionar a paz temporal ou felicidade temporal aos homens, mas com vistas a alcançar a vida eterna, "verdadeira felicidade".

É por isso que, ao elogiar a felicidade temporal alcançada pelos antigos romanos, Agostinho justifica: "pela coisa comum, isto é, pela República, e por seu erário, desprezaram seus interesses privados, resistindo à avareza e deram com liberdade a vida pela pátria [...] E por isto foram honrados em quase todas as nações e impuseram as leis de seu Império a muitos povos" (Idem V, 15). E, como conseqüência por tão sublime gesto de patriotismo, Deus, com o propósito de recompensá-los, "dilatou o Império Romano, para glória humana, mas também com o de que os cidadãos da eterna cidade, enquanto peregrinos no mundo, observem com sobriedade e diligência os referidos exemplos e vejam quanta dileção se deve à pátria soberana por amor à vida eterna, se pela glória humana seus cidadãos tanto amam a terrena" (Idem V, 17).

Como se vê, Agostinho justifica que o poder temporal foi dado por Deus para que os reinos proporcionem a concórdia ou pax temporalis entre os homens, e assim, vivendo de forma reta, possam alcançar a vida eterna ou verdadeira felicidade - finalidade última de todo homem. Assim sendo, Agostinho faz uma estreita relação entre seus principios ético-morais e a finalidade do poder temporal dos reinos.

20 Vejamos o que diz Agostinho: "Sem dúvida, a divina Providência constitui os reinos humanos. Se alguém o atribui à fatalidade precisamente, porque dá esse nome à vontade de Deus ou a seu poder, pode conservar essa opinião, mas deve corrigir o vocabulário" (De Civ. Dei V, 1). E mais do que isso, o reino é um bem em si independente de ser dado a bons ou maus: "O poder de dar o império e o reino não o atribuamos senão ao verdadeiro Deus, que dá a felicidade no reino dos céus somente aos piedosos, e o reino terrestre a piedosos e a ímpios, como the apraz a Ele, a quem nada apraz injustamente" (Idem V, 21). 
Diante de tal finalidade, surge uma questão: Se o poder temporal é um bem em si mesmo (bem menor), dado aos reis para que levem os homens a viverem de tal forma que alcancem a paz eterna, por que Deus o dá a bons e maus? Como justificar as seguintes palavras: "O poder de dar o império e o reino não 0 atribuamos senão ao verdadeiro Deus, que dá a felicidade no reino dos céus somente aos piedosos, e o reino terrestre a piedosos e a ímpios, como lhe apraz a Ele, a quem nada apraz injustamente (grifo nosso)" (Idem V, 21).

A explicação é simples. Da mesma forma como Deus deu ao homem o livre arbítrio, mesmo sabendo ( presciência) que por meio dele alguns homens haveriam de pecar, para que, servindo-se de contraponto, os que usam mal deste tão sublime bem, pudessem justificar o justo prêmio aos bons, assim também acontece com o reino dos ímpios: "Quanto aos que de antemão soube que não havia de livrar, criou-os para utilidade dos que havia de livrar e para comparar entre si, por oposição, ambas as cidades, não inutilmente, mas com belíssima e justíssima ordenação de toda criatura racional (grifo nosso)" (Idem XII, 11); ou seja, "com o fim de o castigo corrigir o castigado e servir de lição aos outros" (Idem XIX, 16).

Assim sendo, mesmo um César Nero, "cuja luxúria foi tal, que se efeminara, e tal sua crueldade, que năo o acreditariam efeminado, se não o conhecessem. Mesmo a esses a Providência do Deus supremo dá o poder de senhorear, quando julga dignas de semelhantes homens as coisas humanas" (Idem V, 19). Ou seja, mais uma vez Agostinho lança mão do princípio de que Deus faz bom uso até das coisas más para o bem do homem. O que na linguagem popular se costuma dizer: "Deus escreve certo por linhas tortas".

Finalmente, como conclusão parcial do exposto, podemos dizer que há uma certa proximidade entre os termos Império Romano e Cidade de Deus, apesar de em nenhum momento Agostinho ter empregado esses dois termos como análogos. O máximo a que chegou foi, em alguns momentos, classificar os antigos romanos como um Império cristão; ou, pelos menos certos imperadores, como por exemplo no final do Livro V, no capítulo 25, de A Cidade de Deus, quando o intitula de: "Prosperidades que Deus concedeu a Constantino, Imperador Cristão".

Mas, ainda no Livro V, paralelamente a essa visão gloriosa do Império Romano, especialmente dos antigos romanos, que seria nomeada por alguns comentadores de "a romanidade" agostiniana, ${ }^{21}$ Agostinho apresenta uma outra visão do Império Romano: a de um império decadente, resultado da vontade má do homem, que usando mal do poder temporal que Deus the dera, ou seja, governando em sua própria honra e glória (soberba), transformou o Império em uma coisa má, passando a ser protótipo da "cidade mística" do mal: Cidade terrena ou ímpia: "Eis que a república romana - diz o Santo Doutor - mudando pouco a pouco, de ótima e formosíssima se transformou em dissolutíssima e péssima [...]" (Idem II, 19). E, citando um dos autores romanos, Catão, acrescenta: "[...] entregamo-nos ao luxo e à avareza, quer dizer, em público, a pobreza, e em casa, opulência. Louvàmos as

21 Cf. RAMOS, Francisco Manfredo T. op. cit. p. 205 e Cf. FÉDOU, Michel. op. cit. p. 21, "A sevcridade de Agostinho não o impede de prestar homenagem à cidade que, até nos tempos de crise, conheceu homens virtuosos e heróis". 
riquezas, seguimos a inatividade. Não fazemos diferença alguma entre bons e maus. Todos os prêmios da virtude estão em poder da ambição" (Idem V, 12). Assim foram alguns romanos. Quando, "perdida a preocupação com a glória, não se viram privados do desejo de dominar" (Idem V, 19).

Assim sendo, Agostinho nos apresenta um quadro contraditório do Império; de um lado, um Estado glorioso, fruto da providência divina; de outro, um Estado decadente (soberbo), fruto da corrupção dos seus governantes.

Mas, a esta visão ambivalente, mais para condescendente do que para critica, expressa nos primeiros livros de A Cidade de Deus, sucede uma segunda fase mais crítica "que se torna mais dura à proporção que progride a controvérsia pelagiana". ${ }^{22}$ Esta fase mais critica encontramos na segunda parte da referida obra quando, já o Livro XV, apresenta o Império Romano não mais como de origem divina, mas como fruto do pecado dos homens, fazendo uma relação direta entre a fundação de Roma e a fundação da Cidade terrena nos dois filhos de Adão, Caim $\varepsilon$ Abel. ${ }^{23}$

A esse mesmo tipo de cidade, nascida da ambição e discórdia entre os homens, a Bíblia havia dado, no passado, o nome de "Babilônia, que quer dizer Confusão" (Idem XVI, 4). Dai, em diversos momentos, Agostinho fazer analogia entre Roma e a Babilônia. ${ }^{24}$

Assim sendo, o Império Romano seria um protótipo da Cidade terrena, a exemplo da Babilônia. E a derrocada do Império, especialmente a queda de Roma em 410, teria um valor paradigmático para todo gênero humano.

\section{Referências bibliográficas}

AGOSTINHO, Santo. A Cidade de Deus: contra os pagãos. 3 ed. Trad. Oscar Paes Leme. Petrópolis: Vozes; São Paulo: Federação Agostiniana Brasileira, 1991, v. I, 414; v. II, 589 p. (Coleção Pensamento Humano).

BIGNOTTO, Newton. O Confito das Liberdades: Santo Agostinho. Sintese Nova fase. Belo Horizonte, 19(58), p. 237-359, 1992.

DANIEL-ROPS [Henri Petiot]. O Santo dos Novos Tempos. In: A Igreja dos Tempos Bárbaros. Trad. Emérico da Gama. São Paulo: Quadrante, 1991, p. 9-62.

FĖDOU, Michel. Santo Agostinho (354-430): A Cidade de Deus, 413-426. In: CHÀTELET, François; DUHAMEL, O.; PISTER, E. (Orgs). Dicionário de Obras Politicas. Trad. Glória de C. Lins e Manoel F. Paulino. Rio de Janeiro: Civilização Brasileira, 1993, p. 26-26.

FORTIN, Ernest L. San Agustín. In: STRAUSS, Leo; CROPSEY, Joseph ( Comps.). Historia de la Filosofia Politica. Méxido: Fondo de Cultura Economica, 1992, p. 170-203.

22 BARDY, G. Apud. RAMOS, Francisco Manfredo T. op. cit. p. 213.

23 "O fundador da cidade terrena foi fratricida. Levado pela inveja, matou o irmão, cidadão da cidade eterna e peregrino na terra. Por isso não é de maravilhar haja tal exemplo, ou, como diriam os gregos, tal arquétipo, sido imitado, depois de tanto tempo, pelo fundador da cidade que com o tempo havia de ser a cabeça da cidade terrena de que falamos e senhora de inúmeros povos. Também ali, como diz um de seus poetas, se regaram com sangue fraterno os primeiros muros. Foi o que aconteceu na fundação de Roma, durante a qual, segundo a História, Rômulo matou o irmão, Remo, com a diferença de aqui serem ambos cidadãos da cidade terrena" (De Civ. Dei XV, 5).

24 Vejamos um desses momentos: "Julgo-me na obrigação de recordar aos reis assirios, a fim de mostrar como Babilônia, primeira Roma, anda de jornada com a Cidade de Deus, peregrina neste mundo [...]" (De Civ. Dei XVIII, 2). E um pouco mais adiante, conclui: "para abreviar o mais possivel, direi que Roma foi fundada como a outra Babilônia, como filha da primeira [...]" (Idem XVIII, 2). 
FRAILLE. Guilherme. San Agustin. In: Histonia de la Filosofia II: el judaismo, el_cristianismo, el islam y la filosofia. 2. ed. Madrid: La editorial Catolica, 1956, 191-231 p. (Biblioteca de Autores Cristianos $\mathrm{BAC})$.

MUÑOZ VEGA, Pablo C. Introduccion a la Sintesis de San Agustin. Quito: Ediciones de la Universidad Católica, 1981, $314 \mathrm{p}$.

RAMOS, Francisco Manfredo T. A Idéia de Estado na Doutrina Ético-Política de Santo Agostinho: um estudo do epistolário comparado com o "De Civitate Dei”. São Paulo: Loyola, 1984, 370 p. (Coleção "Fé e Realidade" n. 14).

SABINE, George. San Agustín. In: Historia de la Teoria Politica. Madrid: Fundo de Cultura Econômica, 1988 , p. 148.

WALKER, Williston. Agostinho. In: Histónia da Igreja Cristă. 2. ed. Trad. Glênio Verga dos Santos e Durval da Silva. rev. Cyril E. Richardson; Wilhelm Panck e Robert T. Handy. Rio de Janeiro: Juerp/Aste, 1980, v. 1, p. 229-239. 